\title{
INVESTMENT AND MANAGEMENT OF TRUST FUNDS IN AN INFLATIONARY ECONOMY
}

Former French Premier, Paul Reynaud, termed inflation "legalized robbery" 1 because, in his opinion, governments engineer it. The "thief" strikes hardest at the purchasing power of those groups with the greatest propensity to save ${ }^{2}$ or with fixed incomes generated by accumulated savings. ${ }^{3}$ Generally, employed Americans are protected through normal salary increases, ${ }^{4}$ while workers covered by escalation clauses gain additional protection as their wages increase in direct proportion to increases in the cost of living. ${ }^{5} \mathrm{~A}$ trustee charged with the management of a fixed sum, however, is not as secure. ${ }^{6}$ Under the pressure of inflation, his position may become unworkable due to the conflicting demands of the life tenant ${ }^{7}$ and the remainderman. ${ }^{8}$

This Comment examines the destructive effect of inflation upon the traditional trust investments of bonds and common stocks and demonstrates that the application of evolving investment theory provides some protection against declining purchasing power, through diversification into the speculative investment opportunities represented by precious metals and real estate. The Comment also analyzes the trustee's legal position and demonstrates that his responsiveness to the often conflicting interests of the life tenant and remainderman is hampered by an inflexibly applied Prudent

1 Wormser, Adjusting Estate Planning to Inflation, in 3 INST. ON Estate Plannivg T 69.500 (P. Heckerling ed. 1969).

2 Savings represent deferred consumption because money saved currently could have been spent on goods and services. By sacrificing the present enjoyment of those things, the saver anticipates that he will be able to enjoy them at some point in the future. The McGraw-HIIx. Dictionary of MOdern Economics 520 (2d ed. 1973). During a period of rising prices, however, a dollar spent currently will purchase more goods and services than one spent in the future. See id. 295. Generally, the income generated by the savings will counteract this lost purchasing power. To the extent that the earnings do not equal or exceed the increase in prices, however, an individual is discouraged from saving.

3 See generally P. SaAuErson, Economics 272 (10th ed. 1976).

4 Torrance, Legal Background, Trends and Developments in the Investment of Trust Funds, 17 Law \& Contemporary Problems 128, 152 (1952).

ธId.

6 Id.

7 The life tenant, see note 132 infra, usually wants the maximum possible income. This traditionally has meant investment in fixed income securities (e.g. bonds), which are notoriously poor hedges against inflation.

8 A remainderman, see note 133 infra, wants the trust principal to increase. Traditionally, those investments most prone to capital appreciation (e.g. growth stocks) have provided low current income. 
Man Rule, the anti-netting doctrine, and the judiciary's reluctance to ease his burden by allowing modification of more restrictive trust instruments. Finally, in addition to noting some countervailing personal and tax considerations which tend to sustain the viability of the trust mechanism in today's economic environment, the Comment suggests that, in order to enable the trust to preserve the purchasing power of the underlying capital, the Prudent Man Rule should be read more flexibly, diversification into more speculative investments should be considered, modification of trust instruments should be made easier, and the draftsman should display creativity.

\section{INFLATION AND INVESTMENT}

\section{A. Inflation and Return on Investment}

Inflation may be defined simply as the erosion in purchasing power of money in circulation. ${ }^{9}$ Persistent inflation has plagued the American economy since the end of World War II. ${ }^{10}$ Consequently, every passing year witnesses a decline in the amount of goods and services that a single dollar can command. ${ }^{11}$ This situa-

9 Professor Samuelson defines "inflation" as "a time of generally rising prices for goods and factors of production ...." P. SAMUELSON, supra note 3, at 270 .

10 The average inflation rate since World War II has hovered between $3^{1 \%} \%$ to $4 \%$ per annum. B. MaLknEL, A Random WaLK Down Warl Street 220 (college ed. 1975). In 1973, the rate of inflation (measured by the increase in the consumer price index) was $8.8 \%$; it subsequently surged to $12.2 \%$ in 1974 , but then slowed to 7\% in 1975 and $4.8 \%$ in 1976. Elia, An Easing of Inflation-Or More InflationSeen Hurting Stocks, Wall St. J., Sept. 27, 1977, at 20, col. 3. Based upon- one monetarist model, the nation's fundamental (three-year) inflation rate is now close to 7.1\%. BusINEsS WEEK, Oct. 24, 1977, at 21.

11 Between 1940 and 1976, the purchasing power of the dollar declined by, more than $75 \%$.

\begin{tabular}{lc} 
& $\begin{array}{c}\text { Purchasing Power of the Dollar } \\
\text { (Base Year 1967 }=\$ 1.00)\end{array}$ \\
Purchasing Power \\
Year \\
1940 \\
(Based on Consumer Price Index) \\
1945 & $\$ 2.381$ \\
1950 & 1.855 \\
1955 & 1.387 \\
1960 & 1.247 \\
1965 & 1.127 \\
1970 & 1.058 \\
1971 & .860 \\
1972 & .824 \\
1973 & .798 \\
1974 & .752 \\
1975 & .678 \\
1976 (May) & .621 \\
\hline
\end{tabular}

U.S. Bureau of the Census, Dep'r of Commerce Statistrcal Abstract of the Untred States 1976, at 432 [hereinafter cited as Statistical Abstract]. 
tion, however, is a relatively new phenomenon; prior to World War I, periods of deflation ${ }^{12}$ were as common as those of inflation. ${ }^{13}$ Although there were major fluctuations in the price index in the period 1776 through 1916, the increases offset the decreases so that the net change was minor. ${ }^{14}$

Return on investment may be defined simply as the sum of the current income and the capital appreciation of the investment. ${ }^{15}$ Any investor is, of course, vitally interested in the returns his investments generate. As long as the rate of inflation remained low and decreases in the value of the dollar were offset by eventual increases, income-oriented investors worried little about the purchasing power of principal and instead focused their concern on the production of current revenue. With the advent of persistent inflation, however, formerly acceptable yields on investments became inadequate because the revenue generated failed to counteract the effects of inflation. ${ }^{16}$ Thus, while all investors needed to be

With an assumed inflation rate of $7 \%$, see note 10 supra, and $\$ 100,000$ in purchasing power at the outset, it will take approximately ten years to destroy one-half the principal's value:

End of Year
1
2
3
4
5
6
7
8
9
10

Purchasing Power
$\$ 93,000$
86,490
80,436
74,805
69,569
64,699
60,170
55,958
52,041
48,398

12 "Deflation" is defined as "a time when most prices and costs are falling." P. SAMUELSON, supta note 3 , at 270 .

13 See Torrance, Legal Background, Trends, and Recent Developments in the Investment of Trust Funds, 17 Law \& Contemporary Problems 128, 145 (1952). The general price level in 1916 was the same as it was in 1776. Note, Prudence in Trust Investment, 8 U. Mich. J. L. ReF. 491, 505 (1975).

14 Note, supra note 13 , at 505-06.

15 A. Gripin, Dictionary of Economic Terms 114 (1973). Capital appreciation is the increase in the market price of the investment itself. Examples include an increase in the price of a common stock or a parcel of real estate. See TriE McGratw-Hill Dictronary of Modern Economircs 25 (2d ed. 1973).

16 During the past 25 years, bonds generated the following yields:

U.S. Government Bonds

Corporate Bonds (Industrials, 40 bonds)

Preferred Stocks (Standard \& Poor's, 10 stocks)

Common Stocks (Standard \& Poor's, 500 stocks)

$\begin{array}{ccc}1950 & 1974 & 1975 \\ 2.32 \% & 6.99 \% & 6.98 \% \\ 2.67 \% & 8.78 \% & 9.25 \% \\ 3.85 \% & 8.24 \% & 8.36 \% \\ 6.57 \% & 4.47 \% & 4.13 \%\end{array}$

Statistical ABstract, supra note 11, at 495 . In 1974, when the annual rate of inflation reached $12.2 \%$, see note 10 supra, none of these yields remotely replaced the eroding purchasing power of the underlying principal. 
concerned with both the income and capital appreciation components of return on investment, traditional investments such as stocks ${ }^{17}$ and bonds ${ }^{18}$ were unable to supply a satisfactory total return. ${ }^{19}$ As a consequence, the market values of portfolios-particularly those composed largely of bonds-dropped tremendously. ${ }^{20}$

Because inflation reduces disposable personal income, ${ }^{21}$ its effects are similar to those of taxes enacted directly by our legislatures; ${ }^{22}$ this "inflation tax" results in the consumption of capital. ${ }^{23}$

17 In 1965, the Dow Jones Average for Industrials (30 stocks) stood at 910.88 . U.S. Bureau of Economic Analysis, Dep't of Commerce, Business Statistics, 1975 EDITION 107 (1976) [hereinafter cited as 1975 Statistics]. During the period 1973-1974, when inflation reached 12.2\%, the Dow Jones Average dropped to a low of 577.60. Malabre, Analysts Say Decline in Market May Persist But See No Recession, Wall St. J., Sept. 29, 1977, at 1, col. 1. This decline would have been even more dramatic had it been adjusted for inflation.

$18 \mathrm{An}$ excellent illustration is long term (20 years), three percent United States government bonds. The value of these bonds (per $\$ 100$ bond) dropped from $\$ 102.53$ in 1950 to only $\$ 57.44$ in 1975 :

$\begin{array}{cc}\text { Year } & \text { Dollar Value } \\ 1950 & 102.53 \\ 1955 & 103.36 \\ 1960 & 86.22 \\ 1965 & 83.76 \\ 1970 & 60.52 \\ 1975 & 57.44\end{array}$

Statistical Abstract, supta note 11, at 496. Previously, these bonds had been considered a safe means of preserving capital while generating adequate income. With the onset of inflation, however, these securities have proved an investment disaster.

19 Introducing taxes into the equation further reduces the actual return. The combined effect of inflation and taxes is confiscatory in operation. A simple example best illustrates the result: Assume an average bond yielding 9.25\%, see note 16 supra, an inflation rate of $7 \%$, see note 11 supra, and a conservative effective tax rate (federal, state, and local) of $40 \%$. The bondholder gains $5.55 \%$ after taxes (60\% of $9.25 \%$ ), but suffers a $7 \%$ loss on principal due to having held the bond for the year. The loss offsets the gain and leaves the investor with a net loss of approximately 1.5\% (measured in constant dollars). If the effects of taxes and inflation are viewed together as one current tax on income, this example illustrates the equivalent of a 116\% rate of taxation: total levies (tax plus inflation) equal $\$ 10.70$ ( $\$ 3.70+$ $\$ 7.00)$; current income equals $\$ 9.25$ (9.25\% of $\$ 100)$; "tax rate" equals approximately $116 \%(\$ 10.70 / 9.25)$.

20 Inflation necessarily leads to increases in the rate of interest as investors seek increased income to compensate for the reduced value of their capital. Prices of already issued bonds will decline until the interest paid yields the new, higher market rate. Those who bought bonds when market interest rates were lower, and thus paid a higher purchase price, will suffer a loss.

21 See note 19 supra.

22 To the extent that the activities of our representatives cause inflation, they may be said to be levying a tax indirectly.

23 The example of a person who places his capital in a $5 \%$ passbook savings account demonstrates this point. A $100 \%$ tax on the interest income when the inflation rate is zero produces the same effect as a $5 \%$ annual inflation rate and no tax. In both cases the saver is left with no real income. Whatever he spends comes directly out of principal. Buffett, How Inflation Swindles the Equity Investor, ForTune, May 1977, at 260. 
The harmful effects are exacerbated by the introduction of the progressive tax structure because higher tax rates are often triggered by illusory increases in value. To the extent that these inflation induced increases force the taxpayer into higher tax brackets, a degree of confiscation exists. ${ }^{24}$ Furthermore, existence of the special method of taxing capital gains which results in lower effective rates only partially mitigates these harmful effects: to the extent that gains are purely the consequence of inflation, there is no addition to the taxpayer's real wealth or purchasing power and the application of any method of taxation amounts to a consumption of capital. ${ }^{25}$

Over the past ten years, the combination of inflation and taxation has severely affected the performance of such investments as bonds and common stocks. At the same time, tremendous new opportunities have arisen, many of them somewhat speculative, in the areas of precious metals and real estate investment. By combining conservative, income-oriented investments with speculative, growth-oriented ones, the financially adept investor may arm himself against the onslaught of inflation.

\section{B. Investment Alternatives}

\section{Bonds}

Because interest rates are fixed in contemplation of inflation, bonds afford a hedge against the existing and expected rate of inflation. ${ }^{26}$ If, however, the inflation rate unexpectedly increases during the term of the bond, a corresponding rise in prevailing interest rates will occur; consequently, the bondholder suffers a decline in value of the bond as the market price drops to adjust the yield to the level of the new interest rate. ${ }^{27}$ Over the past twenty

24 Wormser, supra note 1 , at 【 69.500 .

25 Id. An investor may attempt to avoid the impact of taxes through the purchase of tax exempt municipal bonds. Unfortunately, this would have provided little protection against escalating prices. For example, at the height of inflation in 1974, these investments yielded only $6.26 \%$ (or roughly one-half the rate of price increase). Statistical Abstract, supta note 11, at 495.

26 R. POSNer, Economic ANalysis of Law 197 (1972).

27 Id. Prices of previously issued bonds fluctuate inversely with the interest rate. For example, a bond with a stated interest rate of $6 \%$ should sell at par when the prevailing interest rate is $6 \%$ because an investor cannot obtain a greater return elsewhere and usually will be unwilling to take less. If interest rates increase to 8\%, however, an investor who purchases at that point will be unwilling to pay par for the bond because his yield will only be $6 \%$ when he can get $8 \%$ elsewhere on investments of comparable risk. Thus, such an investor will buy the $6 \%$ bond only at a discount. If the bond were perpetual, the discount off the face value would equal the percentage of increase in the interest rate. (In the example above, 
years, the general trend has indicated a long-term increase in bond yields. ${ }^{28}$ Thus, an investor who purchased bonds with the intention of realizing long-term income has suffered actual losses, because the annual interest has not adequately compensated him for the tying up of his invested capital until the maturity date of the bond.

To some extent, however, bonds may be utilized as hedges against inflation. Bond prices, like prices of common stocks, fluctuate, although the fluctuations usually stem from changes in interest rates rather than from the performance of corporate earnings. ${ }^{29}$ An investor may realize substantial gains by purchasing bonds at times of high interest rates and selling them when the rates decline. ${ }^{30}$ This type of transaction closely approximates speculation because the investor must forecast the direction of short and intermediate term interest rates. Nevertheless, while the general trend of increasing bond yields indicates that interest rates have increased over the long-term, short-term interest rates have fluctuated in both directions. Thus, modern investment strategy dictates that a well balanced portfolio should contain some bonds that are held for their appreciation potential and not simply for the income they generate.

\section{Common Stocks}

Once described as "the most feasible vehicle for combating the inroads of inflation," ${ }^{81}$ common stocks have since lost their attrac-

the discount would be $25 \%-(8 \%-6 \%) / 8 \%)$. Because bonds typically have fixed maturity dates, however, the discount off the face value will be smaller to compensate for the fact that the holder will receive the higher face value at maturity instead of his lower purchase price. The amount of the discount (i.e., increase in the fair market value of the bond) that results from the higher maturity value decreases as the date of purchase approaches the date of maturity.

281975 STatrstrcs, supra note 17, at 105. Bond yields by Moody's Rating:

$\begin{array}{lllll} & \text { Aaa } & \text { Aa. } & \text { A } & \text { Baa } \\ 1947 & 2.61 \% & 2.70 \% & 2.87 \% & 3.24 \% \\ 1950 & 2.62 & 2.69 & 2.89 & 3.24 \\ 1955 & 3.06 & 3.16 & 3.24 & 3.53 \\ 1960 & 4.41 & 4.56 & 4.77 & 5.19 \\ 1965 & 4.49 & 4.57 & 4.63 & 4.87 \\ 1970 & 8.04 & 8.31 & 8.56 & 9.10 \\ 1974 & 8.57 & 8.67 & 9.16 & 9.50\end{array}$

29 This is a general rule. For example, the bonds of a corporation on the verge of bankruptcy will trade at a heavy discount regardless of the interest rate.

30 See note 27 supra. During periods of declining interest rates, the fair market value of bonds will increase. A gain would result on the difference between the lower purchase and the new, higher market value if the investor sold his bonds during such a period.

31 Note, Common Stocks in Trust, 113 U. PA. L. Rev. 228, 259 (1964). 
tiveness. Like bonds, they have failed to perform well in an inflationary environment. ${ }^{32}$ The reasons for their lackluster performance are somewhat unclear. Because common stock represents an equity interest in a company's assets, inflation directly increases the underlying asset value of all stocks. Thus, it would be reasonable to expect that an informed investing public would recognize the increase in underlying asset value and bid up the price of the shares. ${ }^{33}$ However, this analysis overlooks the fact that underlying asset value, like book value, rarely plays a major role in setting the market price of shares of stock. ${ }^{34}$ These values are only important when the corporation is liquidated; because going concerns are rarely liquidated in inflationary times, however, stockholders seldom gain access to these inflating assets..$^{35}$ Furthermore,

because the corporation's assets are combined in a business enterprise, the investment public appraises such factors as the general economic climate, the outlook for the particular industry, the company's competitive position, and the ability of its management, and arrives at a valuation for the stock which may differ materially from the sum of the assets. ${ }^{36}$

Therefore, although the fluctuation of underlying asset value has some relevance for estimating earning power and liquidation value, it exerts little influence on investor activity. Consequently, other factors must explain the dismal performance of common stocks.

Several explanations have been offered for the generally poor performance of common stocks during periods of rapidly increasing prices. First, it has been suggested that, in an economic sense, stocks have come to resemble bonds. ${ }^{37}$ According to the conventional wisdom, the return on equity investments fluctuates from year to year while the returns on particular bond issues remain fixed. Nevertheless, review of the recent history of corporate earnings discloses that returns on book value have stabilized at

32 Buffett, supra note 23, at 250.

33 See id.; Note, supra note 31, at 229.

34 T. Holt, Total INvestang 53 (1976).

$35 \mathrm{Id}$.

36 Note, supra note 31, at 229.

37 Buffett, supra note 23, at 250 . 
approximately twelve percent. ${ }^{38}$ Thus, common stock earnings, much like bond yields, have become fairly constant. The crucial difference, however, is that as the rate of inflation changes, bond yields respond to this change either with concomitant variations in interest rates on newly issued bonds or fluctuations in the fair market values of outstanding issues. ${ }^{39}$ As a result, investors are confronted with a choice between investing in equities-the returns on which are tied to corporate earnings and which, on a percentage basis, are unresponsive to inflation-or bonds, which have interest rates that do reflect fluctuations in the rate of inflation. Because long-term trends have evinced increasing rates of inflation and corresponding escalations in bond yields, ${ }^{40}$ investors have generally chosen to purchase bonds instead of stocks and have liquidated their equity holdings in the process. This selling of stocks in order to buy bonds in turn triggers declines in the stock market. The higher the inflation rate, the more generous bond yields become ${ }^{41}$ and the lower stock prices sink as they fall under increased selling pressure. Furthermore, common stocks will continue to suffer as long as the rate of return on equity investment remains relatively constant.

The effect of constant inflation on the general economic climate reinforces the decline in stock prices. As inflation threatens business profits and investors fear declines in corporate earnings due to anticipated government policies such as restrictive fiscal and monetary programs, common stock prices drop. ${ }^{42}$ The general attitude of the securities markets turns "sour" and investors concentrate on lower risk forms of investment; stock prices drop until their returns, both in the form of dividend yield and potential capital appreciation, rise to levels which induce investors to hold or purchase securities. ${ }^{48}$

Although price levels are constantly rising, the rate of price escalation fluctuates. ${ }^{44}$ At various times price increases taper off, causing the previously stated explanation of poor overall stock per-

$38 \mathrm{Id}$.

39 See note 27 supra.

40 See note 28 supra \& accompanying text.

11 See note 16 supra.

42 B. MALKIEI, supra note 10 , at 221.

43 Id. 221-22.

44 See notes 10-11 supra. 
formance to reverse itself in the short run. ${ }^{45}$ At that point, stocks become attractive, and opportunities to make real profits ${ }^{46}$ from intermediate and short term trading arise. Such activities tend toward speculation, however, and consequently may not be undertaken by the more conservative investor. According to modern investment doctrine, which contemplates such theories as covariance and risk analysis, ${ }^{47}$ such restraint is counterproductive. It must be remembered, however, that regardless of the existence of sophisticated theory, stock market prediction remains an inexact pursuit. This is best illustrated by professional fiduciaries who, even when

given wide investment discretion, generally have not performed as well as the standard indices. ${ }^{48}$ In addition, both in terms of purchasing power and absolute dollar amounts, the market itself has performed poorly over the past dozen years. ${ }^{49}$ The promise of common stocks remains unfulfilled; yet, without question, they merit a place in every balanced portfolio. ${ }^{50}$

\section{Precious Metals}

In 1974, the price of gold was deregulated and the prohibition against ownership of gold by American citizens was rescinded.51 For more than thirty years prior to 1974 , the official valuation of gold had been $\$ 35.00$ per ounce. ${ }^{52}$ Once the price of this precious metal was free to find its own level in the competitive market, however, it soared, reaching its peak at the same time inflation did in December, 1974.53 As the rate of growth in the price level moderated, so did the price of gold. ${ }^{54}$ Although gold has increased

45 See notes 37-41 supra \& accompanying text.

40 Real profits may be defined as gains in purchasing power, not simply increased dollar yield. See D. Moffat, Economics Dictionary 231 (1976).

47 See text accompanying notes 72-77 infra.

48 Langbein \& Posner, Market Funds and Trust Investment Law II, 1977 A.B.F. REs. J. 1, 2-3.

49 See note 17 supra.

50 See text accompanying notes 72-77 infra.

51 Exec. Order No. 11825, 3A C.F.R. 206 (1974), reprinted in 12 U.S.C. $\S 95 \mathrm{a}$ (Supp. V 1975).

52 Thomas, Gold Recovery: More Investors are Switching Out of Paper Money, BARRoN's, April 11, 1977, at 5.

53 The price of gold rose to a high of $\$ 197.50$ per ounce in December, 1974. Id. Inflation reached a peak of $12.2 \%$ that same year. See note 11 supra.

54 By August, 1976, the price of gold had declined to $\$ 103.50$ per ounce. See Thomas, supra note 52, at 5. The price subsequently rebounded to $\$ 175.25$ in February, 1978. N.Y. Times, Feb. 4, 1978, at 31, col. 4 (Afternoon fixing, London). 
in value approximately 500 percent since 1974,55 much of this extraordinary price increase can be attributed to the one-time removal of official restraints. Nevertheless, after the abatement of this initial reaction to Americans' newly-accorded right to own gold, opportunities to make substantial profits on dealings in gold have continued to exist in the free market. ${ }^{56}$ Similarly, the price of silver has shown steady advancement each year, ${ }^{57}$ although its increase has not been as spectacular as the increase in the price of gold. 58

The market values of gold and silver have more than kept pace with inflation. Yet, for all their attractiveness in terms of capital appreciation, both are characterized by three major drawbacks. First, their prices are subject to marked fluctuations, ${ }^{60}$ which fact categorizes them as speculative investments. Second, neither metal produces any current income as compared to bonds, which generate interest, or stocks, which generate dividends. This characteristic is likely to displease the investor interested in high current income from his portfolio. Third, the ownership of these assets may involve a negative present return because storage costs must be paid currently if the metals are warehoused, or, if actual delivery is

55 The price of gold on Feb. 4, 1978 was $\$ 175.25$, approximately five times the prior official price of $\$ 35$ per ounce.

56 Since August, 1976, the price of gold has increased steadily at a healthy rate. See note 54 supra. Furthermore, short term increases have also been good. For example, the price of gold recently increased by $8 \%$ in a little more than 3 months from $\$ 162.90$ to $\$ 175.25$. Compare Wall St. J., Oct. 27, 1977, at 38, col. 6 (Afternoon fixing, London) with N.Y. Times, Feb. 4, 1978, at 31, col. 4 (Afternoon fixing, London).

$\mathbf{5 T}$

$\begin{array}{lc}\text { Year } & \text { Dollars per fine oz. } \\ 1947 & 0.718 \\ 1950 & 0.742 \\ 1955 & 0.891 \\ 1960 & 0.914 \\ 1965 & 1.293 \\ 1970 & 1.771 \\ 1974 & 4.708\end{array}$

1975 Statrstics, supra note 17 , at 100.

In 1977 , the price reached $\$ 4.877$ per ounce. Wall St. J., Oct. 27,1977 , at 38 , col. 6. It subsequently increased to $\$ 5.001$ per ounce in the following three months. Wall St. J., Jan. 27, 1978, at 20, col. 5.

68 Because no comparable restrictions against Americans owning silver existed, the large increase in the price of silver between 1971 and 1974 cannot be attributed to deregulation.

69 For example, the price of gold increased from $\$ 112.50$ to $\$ 197.50$ per ounce in 1974. 'Thomas, supra note 52, at 5.' 
taken, it may be necessary to incur assay costs to determine purity before resale. ${ }^{60}$ Although these drawbacks present some hazards, the potential for capital appreciation cannot be ignored. Thus, in light of modern portfolio strategy, a prudent investor would no doubt be justified in investing some portion of his capital in precious metals. They represent a rational opportunity to preserve some current purchasing power for future generations.

\section{Real Estate}

Real estate, both in the form of undeveloped land and improved land with buildings, has proven to be an excellent hedge against inflation. ${ }^{61}$ Although prices have not been as volatile as those of gold and silver, real estate investment does involve some hazards. Liquidity can be a major problem, both in finding a buyer and then arranging the necessary financing. This procedure, which can be both time consuming and expensive, may force an investor who needs immediate cash either to do without it or sell at distress prices.

During a period of rising prices, the attractiveness of the real estate leads to problems of its own. - As the prospect of capital appreciation lures ever increasing numbers of the investing public, rents tend to fall behind as real estate values surge upward in

60 The investor can avoid assay costs if he holds the metals in the form of coins. The best example of a widely available gold coin is the South African Krugerrand, which contains one ounce of fine gold. Because the coin is currently being minted, numismatic value is limited; thus, the investor confines his risk solely to the value of gold. American silver coins that predate the introduction of the "sandwich" (copper in the middle) in the mid-1960's are traded on the futures market with quotes per $\$ 1,000.00$ (face value) bag listed daily in the Wall Street Journal.

6I The Department of Commerce composite construction cost index reflects the impact of inflation upon construction:

$\begin{array}{cc} & (1967=100) \\ 1947 & 54.0 \\ 1950 & 62.1 \\ 1955 & 72.6 \\ 1960 & 83.1 \\ 1965 & 92.7 \\ 1970 & 120.1 \\ 1974 & 173.0\end{array}$

1975 Statistics, supra note 17 , at 54. As might be expected, the largest jump occurred between 1970 and 1974, when inflation reached its peak. Because new construction competes with existing buildings, the above index gives a good indication of the direction of the entire market. 
response to the increased demand. ${ }^{62}$ The combination of low rent and high potential capital appreciation is tolerable because the net effect is an attractive total return. ${ }^{63}$ Nevertheless, because costs may rise rapidly as rents, remain low, a real estate investor may suffer a current cash shortage while the value of his assets is increasing. ${ }^{64}$ This not only makes the cost of maintaining the investment burdensome, but is likely to dissatisfy the income-oriented investor as the cash available for distribution tends to be small or nonexistent. ${ }^{65}$ In addition, tenant-occupied properties, particularly apartments, generally require close supervision, either by the investor directly or by his agent. In either case, the costs reduce profits and exacerbate any existing cash shortage. Overall, real estate management can entail responsibilities and risks which require abilities beyond those of individual investors.

It was at one time suggested that a lack of expertise in property management could be obviated by the use of the Real Estate Investment Trust (REIT) ${ }^{68}$ By purchasing shares in a REIT, an investor theoretically could participate in the profits attendant upon real estate investment without having to shoulder direct responsibility for the management of the property. Furthermore, because the shares were publicly traded, the problem of liquidity would also be solved. Of course, the REIT managers would receive compensation; however, these costs were expected to be reasonable in an advancing market. Unfortunately, because of weak underlying investments, ${ }^{67}$ the market for REIT's faltered when the stock market did, and both REIT share prices and dividend payouts fell pre-

62 Laden, The Impact of Inflation on the Investor, 114 Trusts \& Estates 22, 24 (1975). The National Association of Home Builders recently estimated: "Rentals .. may be one of the last remaining bargains. The 1976 median rent for new apartments was $\$ 215$ a month, only $13 \%$ higher than the $\$ 190$ figure of 1973 . In the same period the overall cost of living rose $28 \%$ and apartment construction costs soared 32\%." Wall St. J., Sept. 21, 1977, at 1, col. 6.

63 Laden, supra note 62 , at 24.

64 Id.

65 On the other hand, the investor who desires capital appreciation rather than current income will be very satisfied."

66 Note, supra note 31 , at 242 n.67.

67 REITs overreacted during the boom years between 1969 and 1973 when they and their lenders funneled "money into the hands of developers who were busy, in turn, putting up every kind of development, from condominiums in Florida swamps to office parks in New York boondocks." The market eventually became glutted and collapsed. The New Money Target: Profitable Real Estate, Business WeEr, Aug. 1, 1977, at 52. 
cipitously. ${ }^{88}$ Consequently, investors interested in either current income or long-term appreciation were injured by investments in REIT shares despite the tremendous increase in real estate values during the same period. ${ }^{09}$ Thus, as with so many other new investment vehicles, the promise that REITs were once thought to hold has proven to be largely illusory.

Despite the difficulties attendant upon ownership of real estate, it remains a potentially excellent hedge against inflation. The caveat is, of course, that it requires capable management on the part of the investor. A reasonable man would be well advised to place some portion of his portfolio into real estate in order to effect the extremely important diversity of investments that modern theory has shown to be so crucial.

\section{Mutual Funds}

A mutual fund involves the pooling of investors' cash in a common fund to be invested in the market by professional managers. In this way, the investor with limited resources can enjoy the benefits of diversified holdings and gain the services of professionals. ${ }^{70}$ If the money managers were at all times equal to the task, the mutual fund would be an excellent vehicle by which small and intermediate-sized investors could participate in the stock market. A review of professionally managed funds, however, reveals that, on the whole, their investment performance has been worse than that of the personal fund of the amateur investor. Furthermore, when the costs of management and administration are included, it is discovered that professionally managed funds have done worse than the broad market averages, such as the Standard and Poor's 500.71

68 The National Association of Real Estate Investment Trusts stock price index stood at 100 in January, 1972, but dropped to 16.87 in December, 1974. By July, 1976, the index had recovered less than four points to 20.60. NATIONAL Association of Real Estate Investment Trusts, REIT Fact Book 37 (1976) [hereinafter referred to as REIT FACT Book]. Total dividends paid were $\$ 155,260,523$. in October through December 1973 , falling to $\$ 29,652,268$. in October through December 1975 (81\% decrease), while the number of REITs paying dividends fell from 140 to 48 in the same period (65\% decrease). Id. 35 .

60 See note 61 supra. While real estate values were rising, the value of REIT assets was actually falling. In 1974, REITs held assets of approximately $\$ 21.2$ billion; in 1975, the value had declined to $\$ 19.4$ billion. REIT FACT Book, supra note 68 , at 103 .

70 See Lobell, The Mutual Fund: A Structural Analysis, 47 VA. L. REv. 181, 182-86 (1961).

71 Langbein \& Posner, supra note 48, at 2. 
Investors following the conventional wisdom have long approved mutual funds. As in the case of other investments, however, inflation and changing economic environment have caused a redefinition of rational and prudent investment behavior. In view of the poor performance of professional managers, the mutual fund experience may very well prove that there is no substitute for the reasonably astute individual investor, for only he can devote the attention necessary to review each investment within his diversified portfolio. Larger professional funds cannot afford the costs involved in the management of a number of smaller, highly diverse, investments. In light of the poor performance of mutual funds, the small to medium-sized investor will probably be more successful on his own than as part of a large fund.

\section{Investment Strategy}

In the last few decades, investment strategy or portfolio theory has undergone something of a revolution. ${ }^{72}$ The emergence of risk analysis and covariance theory underscores the need for flexible investing. ${ }^{73}$ Current investment strategy looks not only "to individual securities, but also [to] portfolio risk." 74 Based upon covariance theory, an investor should select a balance of various investments, because this results in the reduction of overall risk to the portfolio. ${ }^{75}$ A prudent investor is interested in the maximum return from his total portfolio given a specified degree of risk. ${ }^{76}$ Moderate speculation therefore is rational, particularly when investment risk also includes loss of purchasing power from inflation. By diversifying and mixing speculative with conservative investments, the investor increases the likelihood of securing gains which offset, or at least partially mitigate, the effects of inflation.

72 See Bines, Modern Portfolio Theory and Investment Management Law: Refinement of Legal Doctrine, 76 Conum. L. REv. 721, 734-35 (1976); Note, Trustee Investment Powers: Imprudent Application of the Prudent Man Rule, 50. Notre DaMe Law. 519 (1975); Note, supra note 13, at 508.

73 See generally Note, supra note 13 , at 524-25.

74 Id. 509. The author explains that: "Portfolio risk is dependent upon thecorrelation or covariance among the individual investments, as well as the risk of each component. In other words, the risk of an investment as a part of a portfolio is related to the covariance of that investment with other investments in the portfolio." Id. (footnotes omitted).

75 See id. 509-10; Bines, supra note 72, at 794-95.

70 Note, supra note 13 , at 509. 
Application of current portfolio theory to the previously discussed investment alternatives strongly recommends the use of more than just the traditional bonds and "blue chip" common stocks. A diversified portfolio should contain some speculative bonds, common stocks, precious metals, and real estate. A prudent investor should not commit himself to any one form of investment, but should spread the risk among various forms of investment on the theory that the economic events that might cause the price of one to fall would prompt another to increase. ${ }^{77}$ Therefore, although particular assets may be individually speculative, the total risk of the entire portfolio is reduced by choosing investments with risks that complement each other.

In the area of trust investment, the law has been slow to recognize this shift in portfolio management theory. The law remains tied to principles that were developed during the nineteenth century, when large, regulated securities markets did not exist and the level of understanding of economic problems was much less sophisticated. Current events require the application of the new theories, because past prudent behavior is no longer rational in the prevailing investment environment. The old notions of safety which entailed heavy reliance on the use of bonds and "blue chip" stocks must be discarded and replaced by the concepts of moderate speculation and risk spreading. Armed with this "new" strategy, the investor has a better chance of preserving market power and generating an acceptable level of income.

\section{The Problems of the Trust and the Trustee IN AN INFLATIONARY ECONOMY}

The typical trust ${ }^{78}$ is administered by a trustee who holds legal title to specified property (the res or corpus) and is charged with

77 Covariance between stocks has been illustrated as follows: Company $A$, an automobile manufacturer, earns its best profits (and enjoys its highest stock market price) when the gross national product (GNP) is rising. Company B, a printer of food stamps for the government, reaps its greatest profits (and enjoys its best stock price) when the GNP decreases. These two stocks are said to covary negatively. By purchasing both, the investor decreases the overall risk of the portfolio: when the GNP is falling and Company $A$ is suffering, Company $B$ is booming; conversely, when GNP rises, A does well while B does not. A risklimiting balance has been struck. Id. 510 .

78 Numerous types of trusts exist. See Black's LAw Dictionary 1680-82 (rev. 4th ed. 1968); E. Clatrk, L. Luskx, \& A. Murphy, Graturtous Transferrs 434 ( $2 \mathrm{~d}$ ed. 1977). This Comment, however, is concerned only with express trusts. Express trusts are defined as trusts "created or declared in express terms, and usually in writing, as distinguished from one inferred by the law from the conduct or dealings of the parties." Brack's Law Dictionary 1681 (rev. 4th ed. 1968) 
its management for the enrichment of certain beneficiaries. ${ }^{79}$ Most trusts are managed by institutions-generally banks-which oversee the investment policy and administration of the trust in exchange for a fee. ${ }^{80}$ These managers are generally cautious in their investments, an entirely understandable approach for anyone charged with the care of someone else's money. This caution has been encouraged by the law, which holds the fiduciary liable for failure to exercise proper care in the discharge of his duties. ${ }^{81}$

The diligent manager may wish to alter his traditional investment policy, however, to take account of the effects of inflation on the value of the trust-and, in most cases, he should. ${ }^{82}$ Unfor-

(citations omitted). Depending upon the reason for their existence, private express trusts may be placed into one of two categories: caretaker or dynastic. Friedman, The Dynastic Trust, 73 YALE L.J. 547 (1964). Caretaker trusts usually have an abbreviated term and are designed to safeguard the interests of specific beneficiaries. Rigid safeguards protecting principal may be necessary in order to guarantee their availability for designated purposes. Id. 551. The objective of a dynastic trust is the maintenance of the estate; thus, dynastic trusts are designed for the maximum duration allowed by the Rule Against Perpetuities. Id. 547-49; see Leach, Perpetuities in a Nutshell, 51 HaRv. L. REv. 638 (1938).

79 E. Clark, L. Lusky, \& A. Murphy, supra note 200, at 433.

80 This fee is generally a considerable sum and usually draws from both income (a percentage) and principal (a set sum per thousand dollars of corpus). The cost of a fiduciary thus constitutes a further threat to the real value of a trust. In one sense the rewards of managing a trust justify a stricter attitude towards trustees. It is no longer possible to agree with Lord Hardwicke's view:

If there is no mala fides, - nothing willful in the conduct of the trustee, the Court will always favour him. For as a trust . . . , if faithfully discharged, is attended with no small degree of trouble, and anxiety, it is an act of great kindness in any one to accept it. to add hazard or risque to that trouble, and to subject a trustee to losses which he could not foresee, and consequently not prevent, would be a manifest hardship, and would be deterring every one from accepting so necessary an office.

Knight v. Earl of Plymouth, I Dickens 120, 126-27 (1747). Whatever the increase in rewards trusteeship might justify in terms of accountability of trustees, it certainly entitles the beneficiaries to diligent, attentive, and activist investment strategy, which is, after all, what they are paying for. As fees rise, it seems only fair that beneficiaries should expect more from their managers, and that the law should encourage increased activism.

81 See, e.g., In re Estate of Rothko, 84 Misc. 2d 830, 379 N.Y.S.2d 923 (Sur. Ct. 1975), modified, 56 App. Div. $2 d$ 499, 392 N.Y.S.2d 870 (1977); In re Bond \& Mortgage Guarantee Co., 303 N.Y. 423, 103 N.E.2d 721 (1952); In re Hubbell, 302 N.Y. 246, 97 N.E.2d 888 (195I); G. Bogert, TRUsTs \& TrUSTEEs $\$ \$ 701-08$ (2d ed. 1960); 3 A. Scort, The Law of Trusts $\$ \$ 205-12$ (3d ed. 1967).

82 The necessity of adjusting investment policy will largely depend upon whether the trust is a caretaker trust or a dynastic trust. See note 78 supra. Inflation needs time in order to work its destruction. Because a caretaker trust is usually designed to endure only for a short period, the potential for inflation damage to the corpus is limited. As a consequence, the potential appreciation available from an aggressive investment program is probably not worth the risk of endangering the beneficiary's inheritance. See Friedman, supra note 78 , at 551 . In contrast, the dynastic trust is designed to last for much longer periods. Thus, administrative 
tunately, any effort to do so presents the manager with a dilemma: a more aggressive investment policy may well be in the best interests of the beneficiaries whose interests he guards, but, because of the "protection" afforded the beneficiaries by the law, the manager himself may be liable for any losses sustained by a more speculative series of investments. This is a consequence of the law's failure to recognize that the economy has undergone fundamental structural changes such that nineteenth century rules are no longer applicable to twentieth century portfolio management. Given the impact of inflation, legal attitudes must change to take into account the various problems confronting the modern trustee. First, courts must relax some of the standards applied to fiduciaries generally. Second, courts must be ready to modify overly restrictive clauses in existing trust instruments if they threaten the underlying purposes of the trust, which purposes generally include the preservation of principal. Third, courts must strike a new balance, when necessary, to protect the interests of the income beneficiary, as well as those of the remainderman. A more flexible legal attitude in these areas will probably not compensate for all the losses resulting from inflation, because many managers may have no desire to change their own investment policy. Nevertheless, the law should not do harm, even if it is unable to solve the problem completely.

\section{A. The Legal Standard}

Historically the law has regulated fiduciaries in one of two ways. One system, the "legal list," allows investments only in those securities placed on the official list by the legislature. ${ }^{83}$ The fiduciary is thus assured that an unsuccessful investment will not result in a surcharge, as it was specifically approved by the legislature. The list system originated in England, ${ }^{84}$ and was adopted by many

flexibility is a necessity because rigid rules of investment policy that are unable to adjust to changing market conditions will minimize the effectiveness of the investment manager assigned the task of preserving the purchasing power of the trust. Id.

83 Statutory lists may be either permissive or mandatory. If permissive, investments made outside the list may be allowed if the investor can prove reasonable care and skill. If mandatory, even prudent investments are thought to be breaches of trust. See, e.g., Note, The Reform of the Prudent Investor Rule, 24 MERcen L. Rev. 513, 514-15 (1973). Typically the lists exclude investment in common stock. R. POSNER, supra note 26, at 197.

84 Note, supra note 83 , at 514 . 
states, including Pennsylvania. ${ }^{85}$ Recently, however, these states have been abandoning the list system in favor of the alternative "prudent man" approach. ${ }^{86}$

The Prudent Man Rule was first enunciated in 1850 by $\mathrm{Mr}$. Justice Putnam of the Supreme Judicial Court of Massachusetts in Harvard College v. Amory: ${ }^{87}$

All that can be required of a trustee to invest, is, that he shall conduct himself faithfully and exercise a sound discretion. He is to observe how men of prudence, discretion and intelligence manage their own affairs, not in regard to speculation, but in regard to the permanent disposition of their funds, considering the probable income, as well as the probable safety of the capital to be invested. ${ }^{88}$

The Rule as stated is remarkably flexible. As the court noted: "Do what you will; the capital is at hazard." 89 Any investment includes risk; the taking of these risks is a matter of "prudence, discretion and intelligence." What risks are worth taking vary with changing economic circumstances. The court did note that investments should not be made "in regard to speculation," but in an economic climate in which continued growth is necessary if the invested capital is to keep its purchasing power, men of prudence, intelligence and discretion might well be expected to make some growthoriented, somewhat risky investments-not in regard to speculation, but in regard to preservation of real value.

However flexible the original rule may have been, it has been interpreted more narrowly. The New York decision, King $v$. Talbot, ${ }^{90}$ is perhaps the best known:

$[T]$ he trustee is bound to employ such diligence and such prudence in the care and management, as in general, pru-

85 Act of February 18, 1824, P.L. 25, cited in Stewart, Legal Investments and the Prudent Man in Pennsylvania: A Study of Evolving Concepts, 37 TeMPLe L.Q. 121, 122 n.3 (1964). For many years, New York maintained an intermediate position, permitting half of the portfolio to be in common stock and the rest to be controlled by the legal list. E. CLARK, L. LUSKY, \& A. MURPFY, supra note 78, at 782.

86 This has been the case in Pennsylvania and New York. PA. Cons. STAt. ANN. tit. 20, $\$ 7302$ (Purdon 1975); N.Y. EsT., Powers \& Trusts LAW $\$ 11-2.2$ (a) (1) (McKinney Supp. 1977).

8726 Mass. (9 Pick.) 446 (1830).

88 Id. 461.

s9 Id.

9040 N.Y. 76 (1869). 
dent men of discretion and intelligence in such matters employ in their own like affairs.

This necessarily excludes all speculation, all investments to an uncertain and doubtful rise in the market ....

It, therefore, does not follow, that because prudent men may, and often do, conduct their own affairs with the hope of growing rich, and therein take the hazard of adventures which they deem hopeful, trustees may do the same; the preservation of the fund, and the procurement of a just income therefrom, are primary objects of the creation of the trust itself, and are to be primarily regarded..$^{91}$

Although this attitude may have been reasonable in $1869,{ }^{92}$ in the current era, in which "preservation of the fund" requires considerable growth in dollars, the blanket prohibition on speculation is far too broad. Nonetheless, this decision, and others like it, ${ }^{93} \mathrm{com}$ prise the majority view of what constitutes a "prudent man."

A more sensible attitude is to scrutinize the reasons for an investment decision at the time it is made. Even conservative investments may later prove unwise, and courts have generally absolved the fiduciary of any liability if he can demonstrate considerable care in the selection of the investment. ${ }^{94}$ But a prudent fiduciary may also exercise intelligence and disretion in the decision to make investments in more hazardous securities. In fact, if he balances his choice of risk carefully, the overall risk in the portfolio may decline. ${ }^{95}$ If the Prudent Man Rule is to serve the interests of the beneficiaries, it must allow those who invest for them to takethe same measures to counteract loss of purchasing power that prudent men would take in managing their own affairs. Today such investments do not represent gambles made "in the hope of growing rich," but rather prudent risks designed to keep pace with the growth, real or imagined, of the economy at large. Such invest-

91 Id. 85-86 (footnote omitted).

92 See note 13 supra \& accompanying text.

93 See, e.g., In re Carnell's Will, 21 N.Y.S.2d 376, 379, 260 App. Div. 287, aff'd, 284 N.Y. 624, 29 N.E.2d 935 (1940); In re Hirsch's Estate, 116 App. Div. 367, 101 N.Y.S. 893, 899 (1906), aff d; 188 N.Y. 584, 81 N.E. 1165 (1907); In re Stumpp's Estate, 153 Misc. 92, 274 N.Y.S. 466 (Sur. Ct. 1934).

04 Courts have emphasized the importance of research and review of each investment. See, e.g., In re Pate's Estate, 84 N.Y.S.2d 853 (Sur. Ct. 1948), áff'd, 276 App. Div. 1008, 95 N.Y.S.2d 903 (1950); Fisher Trust, 26 Pa. Fiduciary -Rep. 276 (Orphans' C. Montg. Co. 1976); Estate of Simon, 24 Pa. Fiduciary Rep. 599 (Orphans' C. Erie Co. 1974).

${ }^{95}$ See Note, supra note 13, at 509-10; notes 72-77 supra \& accompanying text. 
ments do not constitute "speculation" in the sense understood by nineteenth century courts; rather they serve as useful tools in the prudent, and, indeed, conservative, management of an entire portfolio. When a fiduciary can demonstrate that his decisions were not ill considered or poorly informed, but, instead, were made with an understanding of the risks involved and as part of an overall investment strategy designed to protect the real value of the trust principal, he should not be held liable by the courts for ultimately unsuccessful investments.

The unfortunate consequences of a narrow reading of what constitutes a "prudent man" can also be seen in the related concept that every investment must be judged separately. ${ }^{96}$ Thus a fiduciary who invests in three speculative securities, and realizes gains on two, but a loss on one, may be surcharged for the one loss, despite the overall success of his investment policy. This rule is called the "anti-netting" doctrine, because it bars the fiduciary from netting his gains on profitable investments against losses on other investments. ${ }^{97}$ Coupled with an inflexibly applied prudent man standard, this rule puts great pressure on fiduciaries to concentrate their investments in well known securities, the prudence of which have already been tested. This is not likely to be in the best interests of the beneficiaries, who are more interested in the overall performance of the fund than in the wisdom of any particular investment.

The anti-netting doctrine may also have unfavorable tax consequences. $^{98}$ Penalizing a trustee for individual losses encourages him to retain a security after its market value has been impaired, rather than to admit openly, through a sale, that an investment error was made. ${ }^{99}$ For tax purposes, these losses remain unrecognized, where they could otherwise have been used to offset capital gains and

96 See, e.g., G. BoGert, supra note 81, \$708; A. ScoTT, supra note 81, \$213. New York provides particularly vivid examples, e.g., In re Bank of New York, 35 N.Y.2d 512, 517, 323 N.E.2d 700, 703, 364 N.Y.S.2d 164, 168 (1974); In re Morgan Guaranty Trust Co., 89 Misc. 2d 1088, 1091-93, 396 N.Y.S.2d 781, 784-85 (Sur. Ct. 1977).

97 See, e.g., Creed v. McAleer, 275 Mass. 353, 362-63, 175 N.E. 761, 762-63 (1931); Vest v. Bialson, 365 Mo. 1103, 1117, 293 S.W.2d 369, 379 (1956); State ex rel. Bottcher v. Barling, 149 Neb. 491, 500-01, 31 N.W.2d 422, 428 (1948); Pennsylvania Co. for Ins. on Lives v. Gillmore, 142 N.J. Eq. 27, 47, 59 A.2d 24, 37 (1948).

98 Note, supra note 72 , at 528 .

99 It should also be noted that continuing to hold a security that has little hope of regaining its former value is a very poor means of allocating resources. Trustees should be encouraged to accept their losses and transfer remaining funds to new investments that promise appreciation. 
reduce the trust's overall tax.100 In an age of heavy taxation, even a loss can have a significant dollar value; the law should not inhibit its recognition. Thus, by admitting a broader definition of the prudent man, and by being ready to judge a fiduciary's performance as a whole rather than investment by investment, courts can encourage managers of trusts to adopt more aggressive investment policies.

\section{B. Ameliorating the Negative Effects of the Trust Mechanism}

Even if the legal standard applied to fiduciaries is relaxed to accommodate investment strategies attuned to the dynamics of an inflationary economy, the fiduciary may uitimately be frustrated by the trust document itself. Many trust instruments were drafted in response to a prior, different, set of economic conditions. Experiences such as the stock market crash of 1929, and, earlier, the deflationary period following the Civil War, led many settlors to assume that any form of speculation should be avoided. Thus, although currently drafted instruments generally permit investment of trust funds in common stock, trust instruments forbidding this investment are relatively common. ${ }^{101}$ Under present economic conditions, however, these restrictions do not protect the real value of the trust principal, ${ }^{102}$ but instead make any efforts to do so virtually impossible.

These restrictions involve difficult legal questions as well as economic problems. Courts are naturally wary of countermanding the specific instructions of a settlor, but it is reasonable to expect that courts will give effect to the settlor's intent even if faultily expressed. $^{103}$ In this context, however, intent may have several

100 I.R.C. $\$ \$ 1201,1211,1212$. To "recognize" a loss the security must be sold or exchanged. I.R.C. $\$ \$ 1001,1002$.

101 See, e.g., the trust instruments of issue in In re Brown's Estate, $408 \mathrm{~Pa}$. 214, 183 A.2d 307 (1962), In re Jeffries' Estate, 393 Pa. 523, 143 A.2d 391 (1958), In re Kelsey's Estate, 393 Pa. 513, 143 A.2d 42 (1958), In re Cope's Estate, 351 Pa. 514, 41 A.2d 617 (1945).

$102 \mathrm{See}$ text accompanying notes 72-77 supra.

103 The Supreme Court of Pennsylvania has stated:

In order to ascertain the actual intent of the settlor or testator, the Court must place itself in his armchair and consider not only the language and scheme of the instrument but also the facts and circumstances with which he was surrounded; and these surrounding facts and circumstances include the condition of his family, the natural objects of his bounty and the amount and character of his property.

In re Trust Estate of Pew, 411 Pa. 96, 107, 191 A.2d 399, 405 (1963) (citations omitted). 
meanings, each of which would lead a court to a different conclu-: sion. An instrument that forbids the fiduciary's investing in com: mon stock manifests a clear intent to forbid that specific method of: investment. The settlor can not be said to have been confused: about the meaning of his words, and he no doubt included them in the instrument for a purpose. In a literal sense, he intended to disallow investment in common stock for the duration of the trust.

On the other hand, the settlor also intended to protect thevalue of the principal.104 His decision to exclude investment in common stock rested on a judgment that the risks of the market. were a threat to the value of his holdings and that steps should be: taken to guard against any threat to that value. Given the economic conditions with which the settlor was familiar, this cautious policy made some sense. He could not have foreseen the widespread, continuous high rates of inflation that have existed since World. War II. Because inflation has proved to be a most dangerous threat. to the value of assets held in trust, the courts, by giving effect to the settlor's command forbidding growth-oriented investment, have. guaranteed the frustration of his underlying intent to preserve the. value of the corpus.

Although it is clear that courts may alter express provisions of a trust instrument under certain circumstances, ${ }^{105}$ difficulties arise in determining what those circumstances are. ${ }^{106}$ One of the most important questions in modern trust law is whether the onset of

104 This statement may not be true in every instance. "For example, a settlor who lived through the Great Depression and saw some stockholders lose everything when the market crashed in 1929 might have been so fearful of losing everything at once that he would prefer to allow the value of the principal to diminish slowly because of inflation rather than invest in stock and see part of the corpus become. worthless overnight. Nevertheless, as increased government regulation has made the chance of another crash remote while present fiscal policies tolerate persistent inflation, investors have become more apprehensive of the destructive power of inflation and more concerned with protecting the purchasing power of trust principal.

10 G. BogERT, supra note $81, \S 561 ; 2$ A. Scotr, supra note 81 , $\$ 161$. For example, modification is thought justified when the authorized securities have become unavailable or impossible to obtain. In re Vogler's Trust, 66 D. \& C.2d 552, 24 Pa. Fiduciary Rep. 400 (1974). desirable:

106 Modification usually is not granted simply because the court thought it was:

Courts cannot, even when aided by hindsight and the ingenuity of counsel, rewrite a settlor's deed or a testator's will, or distort or torture his language or the language of a statute relating thereto, in order to attain what we believe is beneficial and wise, or even what we believe settlor would or should have provided if he had possessed a knowledge of all presently existing circumstances.

In re Kelsey's Estate, 393 Pa. 513, 519, 143 A.2d 42, 45 (1958). 
inflation is a proper circumstance justifying modification. The leading case in the movement towards adoption of the position that inflation is a proper circumstance is In re Trusteeship Under Agreement with Mayo. ${ }^{107}$ The grantor created two separate trusts, one in 1917 and another in 1919, and died in 1939, just prior to the onset of the current period of inflation. In substance, both trusts limited investments to "real estate mortgages, municipal bonds or any other form of income bearing property (but not real estate nor corporate stock)." 108 The beneficiaries and trustees sought modification of these terms in order to permit investment in common stocks. Relying on evidence that, after the donor's death, inflation "had reduced the real value of the trust assets by more than 50 percent ... [and] that a further inflationary period or a permanent 'creeping inflation,' which the donor could not have foreseen, must be expected ...," ${ }^{109}$ the court ordered the requested modification and decided that "unless deviation is ordered the dominant intention of the donor to prevent a loss of the principal of the two trusts will be frustrated." 110 Given current economic conditions, this kind of reasoning should prevail because it recognizes the damage that inflation can cause and that rigid adherence to the grantor's original instructions may actually defeat his intent. Some cases following Mayo have accepted this reasoning and allowed changes in the trust instruments. ${ }^{111}$

Regrettably, many courts are not as farsighted. A substantial body of case law rejects the proposition that inflation constitutes a threat sufficient to justify judicial modification of a trust instrument. ${ }^{112}$ In direct contrast to Mayo is Stanton $v$. Wells Fargo Bank \& Union Trust Co., ${ }^{113}$ in which the court reviewed an instrument that limited the trustee to investment in bonds possessing a rating specified by a certain investors' service. Taking a classically inflex-

107259 Minn. 91, 105 N.W.2d 900 (1960).

108 Id. at 92-93, 105 N.W.2d at 902 (emphasis in original).

109 Id. at 93,105 N.W.2d at 902.

$110 I d$. at 97,105 N.W.2d at 904.

111 Carlick v. Keiler, 375 S.W.2d 397 (Ky. App. 1964); Troost Ave. Cemetery Co. v. First Nat'l Bank, 409 S.W.2d 632, 636 (Mo. 1966); of. Davison v. Duke Univ, 282 N.C. 676, 194 S.E.2d 761 (1973) (the court expressed doubt that the threat of destruction of the dominant purposes of a trust by the ravages of inflation would be insufficient to warrant modification of the trust instrument).

112 Stanton v. Wells Fargo Bank \& Union Trust Co., 150 Cal. App. 2d 763, 310 P.2d 1010 (1957); Toledo Trust Co. v. Toledo Hospital, 174 Ohio St. 124, 187 N.E.2d 36 (1962). See Thomson v. Union Nat'l Bank, 291 S.W.2d 178 (Mo. 1956); Reiner v. Fidelity Union Trust Co., 127 N.J. Eq. 377, 13 A.2d 291 (1940).

113150 Cal. App. 2d 763, 310 P.2d 1010 (1957). 
ible position, the court rejected modification based upon declining purchasing power, and commented:

No emergency exists. The existing inflationary cycle has continued for some years. The government has adopted many economic measures to try to control and stop this inflationary trend. Some economists predict an era of deflation and others warn us of a depression. These matters are mentioned to indicate that, while the settlor may not have been omniscient, neither are the beneficiaries nor the courts, omniscient. ${ }^{114}$

The movement towards the Mayo position is apparent in Pennsylvania. Since 1967, the Commonwealth has allowed modification of a trust instrument at the court's discretion if the court is satisfied "that the original purpose of the testator or settlor cannot be carried out, or is impractical of fulfillment, and that the authorized release will more nearly approximate the intention of the testator or settlor." 115 An amendment clarified any difference that may have existed between the grounds for modification in the statute and Mayo. The statute now permits modification if the court finds "that the existing or reasonably foreseeable economic conditions are so far different from those prevailing at the creation of the trust that adherence to the restriction might deprive the respective beneficiaries of income and principal of the full benefits the testator or settlor intended them to enjoy." 116 The court's power to override even express instructions in the trust instrument "under proper circumstances" is generally conceded.117 The Pennsylvania Act is an eloquent observation that changing economic circumstances constitute just such a "proper circumstance." 118 As such, it

114 Id. at 771,310 P.2d at 1016.

115 PA. Stat. ANN. tit. $20 \S 7319$ (b) (Purdon 1972) (amended 1974), cited in Comment, The Power of the Trustee in Pennsylvania to Deviate From the Investment Provisions of the Trust Instrument, 77 Drcx. L. Rev. 614, 617 (1973). 1974).

116 PA. Cons. Stat. ANn. tit. $20 \S 7319$ (b) (Purdon 1975) (as amended

1172 A. Scotr, supra note 81, at $\$ 167$.

118 "This statute is legislative recognition of the well settled doctrine that an orphans' court has the power to order deviation from the express terms of a trust should the circumstances dictate such deviation in order to carry out the purposes of the trust." In re Stewart Memorial Fund, 22 Pa. Fiduciary Rep. 212, 217 (1971) (citations omitted). See Restatement (Second) of Trusts $\$ \$ 167,381$ (1959). "It is believed that these statutes are in most cases merely declaratory of the existence of a power which the court has as a part of its general equitable jurisdiction." G. BOGERT, supra note 81 , at $\$ 561$. 
should be applied to pre-existing trust instruments and not confined to those drafted after its enactment. ${ }^{119}$

Although the previous suggestions are useful in solving the problems of an existing trust, careful drafting of the instrument is the optimal solution. If the settlor has confidence in the trustee, his attorney should set forth wide powers of discretion in the investment clause, in order that the best interests of the beneficiaries may be served without the necessity of reference to the cumbersome restraints embodied in the Prudent Man Rule. ${ }^{120}$ So that the grantor's intention is perfectly clear, it may be best to specifically authorize a wide and not exclusive range of investment choices. ${ }^{121}$ Of course, any deviation from the Prudent Man Rule merits settlortrustee discussion prior to the establishment of the trust. ${ }^{122}$ In that way, the fiduciary will be apprised of the settlor's expectations before he assumes responsibility for the trust assets.

The grantor who desires a flexible or particularly aggressive investment program should consider appointing an individual trustee who is more aware of the grantor's objectives than an institutional fiduciary. ${ }^{123}$ In view of the poor performance of the large, professionally managed funds, ${ }^{124}$ a capable individual could reasonably be expected to do no worse, and logic suggests that he may well

119 Given the traditional conception of a court's broad equitable power to enforce trusts, there should be no difficulty in applying the Pennsylvania Legislature's definition of "appropriate circumstances for modification" to trust instruments already existing before the 1974 amendment. The court has always possessed the power to modify, although its use has been confined by judicial discretion. Legislative encouragement to modify in changed economic circumstances creates no new power but serves only to encourage the court in the use of that power. As such, it should raise no question of illegal "retroactive" application.

This issue merits attention only because of the unduly restrictive attitude adopted towards $\$ 18$ of the Investments Act by the Pennsylvania Supreme Court in cases such as In re Estate of Brown, $408 \mathrm{~Pa}$. 214, I83 A.2d 307 (1962) and In re Kelsey's Estate, $393 \mathrm{~Pa} .513,143$ A.2d 42 (1958). Although these opinions darkly mentioned a retroactivity problem, both assumed that $\$ 18$ was legal but refused to construe the language of the instruments involved to allow more aggressive investment. Whatever the merit of these decisions, neither refused to apply $\$ 18$ to pre-existing instruments and neither dealt with modification at all. A fiduciary desiring a more aggressive policy might well face a surcharge under these decisions if he sought a more liberal interpretation of the instrument, but they are inapplicable should he ask the court for modification of the instrument. The exact language of an instrument, of course, is unimportant when modification, not interpretation, is the goal.

120 Burch \& Hemmerling, Estate Planning in an Inflationary Economy, $27 \mathrm{~S}$. Cax. Tax Inst., 489, 535 (1975).

121 Id. 535-36.

122 Id.

123 Id. 537.

124 See text accompanying note 71 supra. 
do better because he can devote more personal attention to each asset held in the trust. A large bank or trust company with thousands of trust funds to administer is, on the other hand, forced to deal with each fund on a more impersonal basis. ${ }^{125}$ Furthermore, the large institutions generally are conservative and, therefore, would probably not act as aggressively as the grantor intended even if accorded the suggested broad investment powers. Hence, an individual trustee may prove to be a valuable asset in the trust's battle against inflation.

It is imperative that the grant of investment discretion in the trust instrument be clear and explicit. Courts are generally reluctant to allow variations in the terms of the trust instrument unless extreme or completely unexpected circumstances arise that would impair or defeat the purpose of the trust. ${ }^{126}$ The power to deviate is cautiously guarded; ${ }^{127}$ "[it] is not permitted solely to increase the beneficiary's income, aid one beneficiary at the expense of another, or merely because it would be beneficial to the trust." 128 The Prudent Man Rule can be avoided, ${ }^{129}$ but the language must be clear, ${ }^{130}$ or courts may interpret an investment clause narrowly and find no power to make "nonlegal" investments.131

\section{Balancing the Interests of the Life Tenant and the Remainderman}

A trustee's problems in managing a trust corpus in an inflationary economy are compounded if the beneficiaries do not have similar interests in the trust. For example, a trustee may be re-

$125 \mathrm{See}$ generally Herman \& Safanda, Allocating Investment Information, Financtal ANalysts J., Jan./Feb., 1973, 23, 27-28.

128 Comment, The Problem of Selecting and Drafting an Investment Clause for a Trust, 44 NEB. L. REv. 109, 119 (1965).

127 Id.

128 Id. at 119-20 (footnotes omitted). See In re Trusteeship Under Will of Whelan, 263 Minn. 476, 116 N.W.2d 811 (1962), in which the court that decided Mayo refused to find that unforeseen economic conditions authorized the court to vary the beneficial rights contained in a trust instrument. The court would not exercise its equity power to increase the interests of the life tenant to the detriment of the remainderman (the income beneficiaries wished to increase the amount of the annuities payable to them under the will).

129 See generally In re Clark's Will, 257 N.Y. 132, 177 N.E. 397, 398 (1931): "The testator had an absolute right to provide that his trustee should not be liable for losses accruing from the retention of securities, although it may have been imprudent so to retain them." (citation omitted).

130 The Problem of Selecting and Drafting an Investment Clause for a 'Trust, supra note 126, at 125.

131 Id. 125-27. 
quired to pay out the income to a life tenant ${ }^{132}$ and hold the principal for a remainderman. ${ }^{133}$ This division of interests between successive beneficiaries may lead to a conflict stemming from the life tenant's desire to receive maximum income currently and the remainderman's wish to see the corpus grow, regardless of the income consequences. In an effort to preserve capital in an inflationary period, however, the trustee must focus increasingly on investments that display the greatest promise of appreciation. Were he freed from the necessity of balancing the beneficiaries' conflicting interests, he would accept greater risks and the possibility of a lower income level. Any emphasis upon capital appreciation which deemphasizes current income ${ }^{134}$ may constitute a breach of his duty of impartiality to the life tenant and the remainderman. The trustee thus finds himself compelled to develop a strategy that pursues both a respectable income stream and the preservation of corpus purchasing power. ${ }^{135}$

The law provides very little guidance beyond vague generalizations such as: "If a trust is created for beneficiaries in succession, the trustee is under a duty to the successive beneficiaries to act with due regard to their respective interests." 136 Review of existing case

132 M. Radin, Law Drctronary 191 (2d ed. 1970) defines a life tenant as: "A person who has the right to enjoy certain property for a period measured by his life or that of another named person."

133 Id. 291. A remainderman is "[o]ne who is the owner of an interest or estate in remainder...." Remainder is defined as: "The part of an estate in land which by grant will begin when a particular, i.e., a more limited estate, created at the same time and by the same grant, is terminated." Id.

134 The situation is best illustrated in the case of a growth stock that pays a small dividend and retains its earnings in order to finance additional corporate expansion. Xerox, for instance, paid a dividend of only $\$ 1.60 \mathrm{per}$ share, yielding $3.7 \%$ on a market price of $\$ 43.75$. Wall St. J., Jan. 27,1978 , at 27 , col. 3 . (1972).

135 David, Principal and Income-Obsolete Concepts, 43 PA. B.A.Q. 247, 249

136 Restatenant (SECOND) of Trusts \$232 (1959). The accompanying comment adds little to clarify the meaning intended:

Although the trustee is not under a duty to the beneficiary entitled to the income to endanger the safety of the principal in order to produce a large income, he is under a duty to him not to sacrifice income for the purpose of increasing the value of the principal. Thus, the trustee is under a duty to a life beneficiary not to purchase or retain unproductive property or property which yields an income substantially lower than that which is normally earned by trust investments, although it is probable that the property will appreciate in value ....

On the other hand, the trustee is under a duty to the beneficiary who is ultimately entitled to the principal not to purchase or retain property which is certain or likely to depreciate in value although the property yields a large income, unless he makes adequate provision for amortizing the depreciation.

Id., Comment b. 
law contributes little more in the way of a concrete standard against which a trustee may measure his conduct with respect to the interests of the life tenant and the remainderman. ${ }^{137}$ What is certain, however, is that some effort must be made to protect the beneficiaries' separate interests. ${ }^{138}$

A number of approaches can be taken to accommodate the interests of the different beneficiaries. Regardless of the method chosen, the important act is the realization that, as a consequence of inflation, a clash of interests must occur between the successive beneficiaries of the trust. Because the grantor or testator is, of course, free to specify a desired division of income and principal among the prospective beneficiaries as well as a desired investment policy, the most helpful solutions may be realized in the drafting of the trust instrument itself. Several proposals for use in designing the trust document are currently available to the creative draftsman. The first utilizes the concept of the unitrust-a combination of "the original principal, capital gains and income into a single fund." 139 The trust document would specify that the life tenant is to receive a fixed percentage "of the current market value of the combined fund." 140 Because the value of the fund presumably will fluctuate in response to changes in the purchasing power of the dollar, the income beneficiary should receive some protection against inflation. The choice of an appropriate percentage will involve hazards intrinsic to any projection of adequacy based upon predicted economic conditions. However, the unitrust has the advantage of insulating the life tenant from the risks inherent in any alternative method that would give the trustee discretion to determine the income rate based upon investments made. ${ }^{141}$

A second proposal is based upon "floating apportionment": ${ }^{142}$ The proportions of the fund considered income and principal "float" depending upon the inflation rate and growth rate of the trust portfolio. To the extent that there is capital appreciation in excess of the prevailing rate of inflation, the income beneficiary will

137 See Pennsylvania Co. v. Gillmore, 137 N.J. Eq. 51, 58-59, 43 A.2d 667, 672 (1945); In re Thompson's Estate, 262 Pa. 278, 281, 105 A. 273 (1918); In re Flinn's Estate, 83 PrTr. LEg. J. 131, 131 (1934), aff'd, 320 Pa. 15, 181 A. 492 (1935).

138 See In re Estate of Stillman, 81 Misc. 2d 747, 366 N.Y.S.2d 934, 940 (1975); N.Y. Est., Powers \& Trusts LaWW $\$ 11-2.1(a)(1)$ (McKinney 1967).

139 David, supra note 135, at 251.

140 Id.

141 Id.

142 Comment, Trust Allocation Doctrine and Corporate Stock: The Law Must Respond to Economics, 50 TEXAs L. REv. 747, 771 (1972). 
share in the gains. ${ }^{143}$ In this way, the life tenant will receive increasing income and the remainderman's future interest in the purchasing power of corpus will be preserved. Theoretically, each will receive protection from inflation without damage to the interests of the other, as might occur if the trustee initiates a high income/ low growth plan or high growth/low income approach.

Finally, a grantor particularly concerned with the purchasing power of the life tenant may tie current payments to the Consumer Price Index ${ }^{144}$ or permit the trustee broad powers to invade principal for the support and maintenance of the income beneficiary. ${ }^{145}$ Depending upon the growth rate of the principal, however, this approach may impair the remainderman's interest, which may be acceptable if the settlor is more concerned about the life tenant than the succeeding beneficiaries.

Any of these three methods has the advantage of giving the trustee flexibility to match his investment policy to the prevailing economic conditions without injuring the divergent interests of the various beneficiaries. If deflation occurs, he can pursue the goal of high income without impairing the purchasing power of principal. Conversely, in time of inflation, he can stress growth without lowering the current income of the life tenant.

A trust instrument that is not carefully drafted to guide the trustee in balancing the interests of the different beneficiaries makes the trustee's task much more difficult in the current inflationary environment. Nevertheless, a large number of existing trust instruments pose such a problem for their trustees. In these instances, a logical approach for the investment manager is diversification of the portfolio. ${ }^{148}$ By purchasing high yield stocks and bonds and growthoriented, somewhat more speculative investments, a trustee can balance the life tenant's desire for income and the remainderman's interest in the future value of the principal. ${ }^{147}$ Unfortunately, this

143 Id. 771-79. The author illustrates with the following facts: Begin with a $4 \%$ inflation rate (based upon the consumer price index) and a $7 \%$ growth rate of the trust portfolio. Assume $\$ 100,000$ was originally invested in common stocks paying a 3\% dividend. At the end of the first year the "floating principal" would rise to $\$ 104,000$ (4\% inflation rate applied to $\$ 100,000$ principal). That would leave $\$ 3,000$ in "extra" appreciation: ( $\$ 100,000$ (principal) x 7\% (growth rate)) $\$ 104,000$ ("floating principal") $=\$ 3,000$. The income beneficiary would receive a total of $\$ 6,000$ ( $\$ 100,000 \times 3 \%$ dividend rate plus $\$ 3,000$ "extra" appreciation). The above facts are a simplified illustration of the "floating apportionment" scheme; the actual situation is, of course, complicated by such factors as fluctuating growth, inflation rates, and income taxes.

144 See Burch \& Hemmerling, supra note 120, at 529-30.

145 See id. 538-39.

140 See Comment, supra note 142, at 767.

147 Id. 
does not provide the final solution; the trustee must still determine what the appropriate mix should be in a given instance to provide the "proper" return to each beneficiary. Ideally, the overall return on the trust corpus would provide both a "fair" rate of return for the life tenant as well as reasonable maintenance of purchasing power for the remainderman. If this standard proves to be unworkable, however, a rough notion of equality between the different beneficiaries will prevail in most cases; ${ }^{148}$ alternatively, other situations may call for favoring one beneficiary over another. ${ }^{140}$ This analysis, however, provides no guidance to the trustee in determining what total return he should attempt to realize and what level of risk is acceptable. Furthermore, the trustee's problems are compounded because he must also determine what constitutes a "fair" rate of return to the life tenant. The trustee must evaluate these considerations and then diversify the portfolio accordingly. Thus, a trustee would welcome as much guidance as possible from the trust instrument in order to simplify his decisionmaking and insulate him from liability to a dissatisfied beneficiary.

\section{Countervailing Considerations}

The above survey of the traditional trust investments (bonds and "blue chip" common stocks) reveals their failure to maintain purchasing power in an inflationary period. Diversification and risk spreading among more speculative stock and bond issues, precious metals, and real estate offer some protection, but these countermeasures by no means guarantee successful preservation of purchasing power. Furthermore, strait-jacket fiduciary standards make difficult the adoption of whatever partial solutions have been devised. In short, trusts and trustees are confronted by an exceptionally hostile investment environment.

Although a grantor may realize that the commitment of assets to a trust will result in the erosion of their long term value, various personal or tax reasons may still make it advantageous for him to use this legal device. Such personal considerations may include an incompetent, infirm, or spendthrift beneficiary. For example, a parent may feel that none of his children has the requisite interest

148 If the overall return on principal is insufficient to satisfy both the life tenant and remainderman, the deficiency should be shared equally by both beneficiaries; conversely, if the portfolio return exceeds what is necessary to satisfy both demands, the excess should be divided equally.

149 For example, a testator may create a trust that gives a life interest to his surviving spouse and remainder to his children. In that instance, the testator may be more concerned with ensuring an adequate income for the support of his surviving spouse than with the amount his children ultimately receive. 
or ability to manage large amounts of capital. By restricting access to these assets for at least one generation, he may insure that the basic needs of his offspring will always be met. Furthermore, the grantor may wish to protect his child from a potentially disastrous marriage. By making his child the income beneficiary of a trust, the grantor may prevent an improvident spouse from wasting the capital he bequeathed. Thus, the trust provides a mechanism for safeguarding family assets despite the mistakes that individual members may make in their personal lives.

The desire to minimize estate taxes may also lead to use of the trust mechanism to accomplish generation-skipping transfers. ${ }^{160}$ Under current federal estate tax law, assets are, as a general rule, subjected to a levy based upon their market value at the date of death. ${ }^{15 \mathrm{x}}$ In the simple case, the parent leaves everything to the child who, in turn, leaves everything to the grandchild, and so. on. At each death, a tax is imposed on the value of the assets transferred. to the next generation. ${ }^{152}$ Through the trust, however, the tax on the middle generation may be skipped or at least mitigated..153 If, however, most or all of the assets escape taxation at the child's death, these tax savings may offset the losses suffered through inflation.

\section{Conclusion}

Since the Second World War the value of the dollar has fallen tremendously. ${ }^{154}$ Those sections of the economy dependent upon accumulated savings find that the returns generated are inadequate, and, when the effects of inflation and taxation are considered, that invested capital is actually consumed. Due to the nature of the assets of which they are composed; trusts can be particularly vulner-

$150 \mathrm{~A}$ detailed discussion of generating skipping transfers is beyond the scope of this article. For a closer examination, particularly in view of the changes made by the 1976 Tax Reform Act, see Dodge, Generation-Skipping -Transfers After the Tax Reform Act of 1976, 125 U. PA. L. REv. 1265 (1977); I.R.C. $\$ \$ 2601-22$.

151 I.R.C. $\$ \S 2001,2031,2051$.

152 I.R.C. $\$ 2001$.

153 I.R.C. $\$ 2613$ (b)(6) (up to $\$ 250,000$. distributed to grandchildren of the grantor is excluded from the tax).

The mechanics of generation skipping may be illustrated simply: Parent creates a trust to receive assets upon his death; his child is named the life tenant and his grandchild the remainderman. At the child's death, the income interest would expire and, prior to 1976, leave nothing in the child's estate to be valued for tax purposes. Since the Tax Reform Act of 1976, however, some portion of the trust may be subject to tax at the time of the child's death. Dodge, supra note 106, at 1265.

154 Based upon the consumer price index $(1967=100)$, prices were:

$\begin{array}{lrl}1947 & 66.9 & 1975 \text { STATISTICs, supra note } 17 \text {, at } 41 . \\ 1977 \text { (Sept.) } & 184.0 & \text { BusINESS WEEK, Nov. } 7,1977 \text {, at } 2 .\end{array}$


able to the combined attack of inflation and taxation. This, in turn, places the trustee in a most difficult position: he finds himself restricted by the generally inflexible Prudent Man Rule, the antinetting doctrine, courts unwilling to grant modification to existing trust instruments, and the requirement that he engage in a difficult balancing of interests between the life tenant and remainderman. These rigid standards, coupled with the poor performance of traditional trust investments, have left trusts crippled, and have deprived many beneficiaries of part of the value of their inheritance. The economic harm has been so extensive that grantors should analyze all alternatives before committing assets to long term trusts. When it is decided that personal or tax considerations justify the creation of a trust, a number of steps must be taken to minimize the damage that inflation may cause. These steps include a more flexible reading of the Prudent Man Rule, trust portfolio diversification, liberal modification of trust instruments, and the inclusion of broad investment powers in newly created trusts. All may provide some degree of shelter from inflation, particularly in the case of a short-term trust. 